\title{
TOWARDS AN INCLUSIVE AND COLLABORATIVE AFRICAN BIBLICAL HERMENEUTICS OF RECEPTION AND PRODUCTION: A DISTINCTIVELY SOUTH AFRICAN CONTRIBUTION
}

Gerald O. West

School of Religion, Philosophy, and Classics

\& Ujamaa Centre

University of KwaZulu-Natal

\begin{abstract}
In a recent article I characterised the biblical hermeneutics of James H. Cone as a hermeneutic of radical reception and the biblical hermeneutics of Itumeleng Mosala as a hermeneutic of radical production. In this article I argue that though a hermeneutic of reception is the distinctive feature of African biblical hermeneutics, a hermeneutic of production is a particular and distinct contribution by South African biblical scholarship to African biblical scholarship. The article then reflects on how these two hermeneutics might intersect through the inclusion of ordinary African readers of the Bible in both the reception process and in a collaborative analysis of the contested sites of the Bible's production.
\end{abstract}

Keywords: Ideology; Redaction; Reception; Production; African

\section{Introduction}

South African biblical scholarship has been at the forefront of an insistence on the recognition of a hermeneutics of production. While much African biblical scholarship tends to work with the biblical text in its final form, there is a trajectory within African biblical scholarship which argues for the importance of an analysis of the Bible's processes of production. This article analyses the formative work done by African biblical scholarship during the 1980s, focussing on the work of South African scholars Gunther Wittenberg and Itumeleng Mosala, but making reference to others, like Justin Ukpong from Nigeria. My article will place considerable emphasis on the significance of a hermeneutic of production, given that this is a particularly significant contribution of South African (African contextually engaged) biblical scholarship to African biblical hermeneutics. ${ }^{1}$

However, the article will also analyse the importance of a hermeneutic of reception within African biblical scholarship. African reception of the Bible is what is most

This rather awkward formulation, "South African (African contextually engaged) biblical scholarship", is necessary for 'South African' biblical scholarship is not homogeneous, with fairly distinct racial and cultural orientations; see for example Gerald O. West, Biblical hermeneutics of liberation: modes of reading the Bible in the South African context, Second Revised ed. (Maryknoll and Pietermaritzburg: Orbis Books and Cluster Publications, 1995), 47-59; Madipoane Masenya and Hulisani Ramantswana, "Anything new under the sun of South African Old Testament scholarship? African Qoheleths' review of OTE 1994-2010," Old Testament Essays 25 (2012); Maarman S. Tshehla, "Africa, where art thou? Pondering post-apartheid South African New Testament scholarship," Neotestamentica 48, no. 2 (2014). 
obviously 'African' about African biblical scholarship. African contextual realities are foregrounded, constituting the starting point of African biblical scholarship. As Ukpong so eloquently put it, African biblical scholarship "seeks to make the African ... context the subject of interpretation", which means that every dimension of the interpretive process is "consciously informed by the world-view of, and the life experience within that culture" (Ukpong 1995:5).

Given the early (1960s) disciplinary formation of African biblical scholars, trained within (Western/Euro-American) historical-critical method (LeMarquand 2000; Holter:2002), the insistence on the African context as the subject of interpretation has a distinctly post-colonial orientation, though African biblical scholarship has preferred until recently to speak of an 'inculturation' or a 'comparative' orientation (Ukpong 1995; Ukpong 2000a). South African biblical scholarship, as a particular variant form of African biblical scholarship, has foregrounded the ideological dimensions of inculturation hermeneutics, insisting that context and text are always brought into dialogue/conversation/contestation via a mediating post-colonial theoretical orientation (West 2016a).

\section{A hermeneutic of production}

In the midst of the struggle against apartheid in the 1980s, Itumeleng Mosala engaged in a vigorous critique of the biblical hermeneutics of both South African and African American Black theologians. Allan Boesak and James Cone came in for particular scrutiny (Mosala 1989a:13-42). I have analysed Mosala's critical engagement with both Boesak and Cone in detail. ${ }^{2}$ However, though both Boesak and Cone have training in biblical studies, their primary orientation is theological, so it could be argued that Mosala is being somewhat demanding in his critique of their biblical hermeneutics. However, Mosala's contention is that how we do our biblical hermeneutics has theological implications. Indeed, I will argue, Mosala might claim that how we do our biblical interpretation in contexts where the Bible is a significant sacred text is in itself theological. Theory and method are theological.

I will return to Mosala's trenchant analysis and its theological implications in due course. My point here is that Mosala's critique is founded on a particularly 'biblical studies' understanding of the Bible. That the Bible is the product of particular sites of production is axiomatic to the discipline of biblical studies. Justin Ukpong, for example, makes it clear that "the biblical text itself is not acultural and universal, rather it is steeped through and through in the culture and life experiences of those communities that produced them" (Ukpong 1995:6). And though as "[a] preliminary condition for doing inculturation hermeneutic is awareness of, and commitment to, the inculturation movement which seeks strong interaction of the Christian faith with all aspects of African ... life and thought" (Ukpong 1995:10), the "first step in the interpretation process" requires "identifying the interpreter's specific context that dynamically corresponds or approximates to the historical context of the text, and clarifying his/her perspective in relation to the text" (Ukpong 1995:10). An African hermeneutic of reception requires a hermeneutic of production.

See, respectively: West.2019. Biblical hermeneutics of liberation; Gerald O. West.2019 The Bible and/as the lynching tree: A South African tribute to James H. Cone, Missionalia 46, (2),

http://missionalia.journals.ac.za/pub/article/view/312. 
Biblical studies as a discipline has a well-worn set of methodological resources for identifying a text's site of production, and African biblical scholars like Ukpong deploy them in a systematic manner. Historical-critical tools are used to identify and delimit a particular 'text' within its particular historical site of production (Ukpong 1996:194204). Since the 1970s, sociological methods and models have been used alongside or integrated with historical analysis in order to thicken the social dimensions of historically reconstructed sites of production. ${ }^{3}$ Indeed, Norman Gottwald's pioneering work, The Tribes of Yahweh: A Sociology of the Religion of Liberated Israel, 1250-1050 B.C., which was formative for both Wittenberg and Mosala, made the bold claim that sociological models are (and should be) constitutive of historical reconstructions (Gottwald 1999:16-17). ${ }^{4}$

Gottwald's point is that historical data is not ideologically innocent, and is always given a particular historical shape by an interpreter's (whether ancient or contemporary) ideological orientations. The historian Hayden White made a similar point, using a broader notion of ideology, in his analysis of the "tropes" of historical reconstruction (White 1978). But the trajectory within South African biblical scholarship I am analysing here uses a more orthodox Marxism-informed notion of ideology, following Gottwald, where ideology has explicitly economic dimensions. ${ }^{5}$ As African biblical scholars, both Wittenberg and Mosala acknowledge and embrace the ideological role of the African reader, but they insist that the biblical text too is an ideological product. This is their distinctive contribution to African biblical scholarship.

The particular emphasis of South African (African socially engaged) biblical scholarship has been on the ideological nature of a text's site of production. Biblical texts are indelibly etched with the ideological markers of their sites of production. ${ }^{6}$ The plural 'sites' here is important, for among the historical-critical methods, South African biblical scholarship has given special attention to the ideological dimensions of redaction criticism. The Bible, as we have it in its final form, is the product of successive sociohistorical processes of collection and composition, known as redaction, with each and every socio-historical moment of (re)collection and (re)composition having a particular ideological site of production. More significantly, South African biblical scholarship has argued that the process of redaction is ideologically contested, so that the Bible is itself, intrinsically and inherently, a site of ideological struggle. Redaction is not additive but ideological. Redaction, to use a recent South African expression, 'captures' the ideological identities and voices of the texts it co-opts and redacts.

As Mosala sets out to demonstrate his understanding of the redaction process in his seminal 1980s work with respect to the biblical book of Micah, he invokes this axiomatic

See the insightful analysis in: Lategan, Bernard C.Current issues in the hermeneutical debate,

Neotestamentica 18; Chaney, Marvin L. Micah - models matter: political economy and Micah 6:9-15, in

Esler, Philip F. (ed), Ancient Israel: the Old Testament in its social context, Minneapolis: Fortress Press.

4 Though not as clear in her formulation, Elisabeth Schüssler Fiorenza's 'feminist' sociological method frames her historical reconstructions; see Fiorenza Elisabeth Schüssler. In memory of her: a feminist theological reconstruction of Christian origins. London: SCM.

5 See Per Frostin's careful contrasting of Boesak's and Mosala's notions of ideology: Frostin Per. Liberation theology in Tanzania and South Africa: a First World interpretation. Lund: Lund University Press, 165-66.

6 Mosala would, I think, acknowledge Stephen Fowl's interrogation of the notion that texts 'have' ideologies, but would want to insist that significant features of a text's production are ingrained in the text; see Fowl, Stephen. 1995. Texts don't have ideologies, Biblical Interpretation 3; West, Gerald O. 2004. Taming texts of terror: reading (against) the gender grain of 1 Timothy, Scriptura 86. 
understanding of biblical scholarship: "Biblical scholars have always been aware of the tendency in biblical literature for older traditions to be reused to address the needs of new situations. ... This practice has, in fact, been seen as a natural order of things in the internal hermeneutics of the Bible" (Mosala 1989a:101). Among those Mosala cites to support this claim is the work of South African biblical scholar Ferdinand Deist. What is significant about Mosala's choice of Deist's work is that Deist is overt about how older texts are ideologically reused in order "to authorize the new" (Deist 1982:65; Mosala 1989a:101). Deist, like Mosala, insists on South African biblical scholarship being attentive to the ideological dimensions of the Bible, at a time when much of white South African biblical scholarship was avoiding the ideological dimensions of biblical interpretation (Smit 1990; Draper 1991).

Mosala's second citation is equally telling, for he cites the biblical-theological work of Gerhard von Rad, which resonates here rather well with Mosala's own theological worries about the final redactional form of the Bible. Von Rad makes the point that in the reuse of older texts, "the factual historical data [of the older traditions] can no longer be separated from the spiritualizing interpretation, which penetrates everything" (Von Rad 1975:118; Mosala 1989a:101). The ideological diversity of older traditions, what Von Rad refers to as "the old disassociated traditions", are given through later redactions "a reference and interpretation which in most cases was foreign to their original meaning". Von Rad, cited by Mosala, goes on to add that "the [later] reader is not aware of the tremendous process of [theological] unification lying behind the picture given in the [redacted] source documents" (Von) Rad 1975:118; Mosala 1989a:101). In Mosala's terms, redactional ideo-theological "co-optation" is an inherent and intrinsic aspect of any and every biblical text (Mosala 1989a:188). ${ }^{7}$

Mosala's particular problem with Boesak and other black theologians is that by neglecting to discern the ideological character of a particular biblical text they participate in the Bible's ideo-theological co-optation and perpetuate within contemporary contexts ideo-theological co-optation. A hermeneutic of reception (on its own) "conceals the hermeneutically important fact that the texts of the Bible, despite being overladen by harmonizing perspectives, are problematical - if only because they are products of complex and problematical histories and societies". By this Mosala means "that as products, records, and sites of social, historical, cultural, gender, racial, and ideological struggles, they radically and indelibly bear the mark of their origins and history" (Mosala 1989a:20). The "ideological aura" of the final form of the biblical text, often referred to by African Christian believers as "the Word of God" (Mosala 1989a:20), obscures and obfuscates the historical reality of the contending ideologies 'behind' the Bible's final form. "A black biblical hermeneutics of liberation", Mosala insists, "must battle to recover precisely that history and those origins of struggle in the text and engage them anew in the service of ongoing human struggles" (Mosala 1989a:20). It is only "[w]ith the agenda of the text laid bare", Mosala contends, that "we can make hermeneutical connections with similar agendas in the contemporary setting" (Mosala 1989a:185).

I use the term 'ideo-theological', admitting as it does to both ideological and theological dimensions to interpretation; see: West, Gerald O. 2009. Interpreting 'the exile' in African biblical scholarship: an ideotheological dilemma in postcolonial South Africa, in Becking, Bob, and Human, Dirk (eds), Exile and suffering: a selection of papers read at the 50th Anniversary Meeting of the Old Testament Society of South Africa OTWSA/OTSSA, Pretoria August 2007, ed. Bob Becking and Dirk Human Leiden: Brill. 
Mosala is confident that biblical scholarship is able to discern that sites of production are indeed sites of ideological contestation. However, he is sceptical that "the struggles and projects of the oppressed peoples in biblical communities" are readily apparent (Mosala 1989a:152), even to biblical scholarship. Successive co-optation by dominant ideologies through successive redactional processes has meant that the presence of oppressed sectors is almost entirely absent. Mosala laments "the absences in the text of material concerning the experiences of the oppressed in ancient society" (Mosala 1989a:152), but recognises that "while the oppressed and exploited peasants, artisans, day laborers, and underclasses of Micah's Judah are entirely absent in the signifying practice that the wider text of Micah represents, something of their project and voice has almost accidentally survived" in the redacted texts that have co-opted their struggles and projects (Mosala 1989a:152).

"The task of a biblical hermeneutics of liberation", therefore, "is to go behind the dominant discourses [represented in the final form of the Bible] to the [co-opted] discourses of oppressed communities in order to link up with kindred struggles" (Mosala 198a9:153). The final form of the Bible is a "contradictory" or contested text (Mosala 1989a:152); "the texts of the Bible are sites of struggle" (Mosala 1989a:185). As James Scott argues, in most contexts of domination "the terrain of dominant discourse is the only plausible arena of struggle" (Scott 1990:102-3). Given this reality, the importance of contemporary struggles for liberation as a biblical exegetical resource is, as Mosala insists, that "there are enough contradictions within ... [biblical texts] to enable eyes that are hermeneutically trained in the struggle for liberation today to observe the kin struggles of the oppressed and exploited of the biblical communities in the very absences of those struggles in the text" (Mosala 1986:196). The contradictions are embodied textually inscribed - within the final form of the text because, insists Mosala, the Bible is itself "a product and a record of class struggles" (Mosala 1986:196). Black theologians, because of their social location within the struggle against apartheid, were able, Mosala argues, to detect "glimpses of liberation and of a determinate social movement galvanized by a powerful [liberation] religious ideology in the biblical text" (Mosala 1989a:40). But because of the "middle-class origins and character" of South African Black Theology (Mosala 1989a:96), even Black Theology required an interpretive alliance with the epistemological eyes of the most oppressed, whom Mosala refers to in class terms as "the "commoners"" (Mosala 1989a:97). So the exploited classes have an exegetical contribution to make, working alongside biblical scholars in recovering what has been co-opted through redaction. I will return to this significant recognition later.

Mosala's method for going "behind the dominant discourses" is itself a substantive ideo-theological formulation. Mosala offers an analogy of method as an ideo-theological resource: in the same way that contemporary social sites are sites of struggle, so biblical texts too are sites of struggle, indelibly marked as they are by their ideo-theological contested sites of production. Interpretive method is an ideo-theological resource. This foregrounding of method, recognising the ideo-theological capacities of method, is Mosala's distinctive contribution to African biblical interpretation. Mosala's contribution goes beyond historical-critical and historical-materialist sociological method's subverting of theologically determinative interpretations of the Bible. His contention and contribution is an understanding of the Bible itself - inherently, 
intrinsically, and indelibly - as a site of struggle, a conceptualisation, he believes, should carry ideo-theological import.

Biblical scholarship as a discipline emerged as a response, in part, to the church's control of the Bible through theology, interrogating theologically determinative interpretations of (ideo-theologically diverse) biblical texts. ${ }^{8}$ Like Ukpong, Mosala does not shirk the theological in African contexts in which the Bible is a significant sacred resource, but reconceptualises it. While Mosala foregrounds hermeneutical method as an ideo-theological resource (West 1995:74-75), Ukpong foregrounds the ideo-theological dimension itself. "The goal of interpretation", Ukpong argues, "is the actualization of the theological meaning of the text in today's context so as to forge integration between faith and life, and engender commitment to personal and societal transformation" (Ukpong 2000b:24). Wittenberg makes similar methodological moves to both Ukpong and Mosala, but emphasises the economic and political dimensions of theology more than Ukpong, and is more optimistic than Mosala about the textual presence of what he refers to as "resistance theology" (Wittenberg 2007).

For Mosala, ideo-theological redactional co-optation of peasant/working-class struggles is a distinctive feature of the final form of the biblical text, and so, often, "[t]he category of the 'black struggle' as a hermeneutical factor draws its poetry from a future that [,] in this struggle's collision with ... [much of the biblical text as we have it] [,] is experienced as an 'absence"” (Mosala 1989a:188). So, as I have already noted, Mosala finds only the already co-opted voices of "the oppressed and exploited peasants, artisans, day laborers, and underclasses of Micah's Judah ... in the signifying practice ... of [the final form] of Micah" (Mosala 1989b:152). By focussing on the final form of the biblical text, Mosala warns, we find only the absence of marginalised voices. However, "their project and voice" is not entirely lost (Mosala 1989b:152), for this absence is partially present precisely because redactional processes do not entirely eradicate the voices they co-opt. 'Accidental' remnants of marginalised voices remain. The poetry that Mosala refers to is the capacity of future contexts of struggle, such as the black South African struggle of the 1980s, to provide avenues of access to the fragmentary presence of ideologically redacted and co-opted social sectors. If Africans persist in their use of the Bible, there is an ethical imperative to engage in such African Marxist socio-historical ideo-theological poetry (West 2020).

Like Mosala, Wittenberg locates resistance in historical communities of struggle, both ancient and contemporary. The persuasiveness of Wittenberg's argument for a pervasive "resistance theology" within the Old Testament/Hebrew Bible resides partially in his location of resistance theology within a particular sector of ancient 'Israel', the am ha'aretz, "the Judean 'people of the land"" (Wittenberg 2007:18). Though the resistance theology of the am ha'aretz takes form in its engagement with the rise of the monarchy, Wittenberg is careful to demonstrate the political and economic significance of this sector prior to the changes wrought by monarchy. The "men of Judah", in Wittenberg's analysis, are Judah's relatively stable, relatively prosperous, and relatively educated "traditional leadership" (Wittenberg 2007:57), representing the rural agricultural community of the am ha'aretz. Wittenberg sees this sector as the repository of an early

See for example the following book, and a response by a South African biblical scholar: Moore, Stephen D. and Sherwood Yvonne. 2011. The invention of the biblical scholar: a critical manifesto Minneapolis: Fortress Press; Dijkhuizen, Petra. 2013. The state of our discipline, Neotestamentica 47(2). 
Judean agriculture-based wisdom tradition, which drew on the Egyptian wisdom traditions that characterised "Judean towns which had long been under direct Egyptian control" (Wittenberg 2007:57). Importantly, the am ha'aretz retained a substantial independence, rooted in their ownership of rural land, their memory of "a period in their history when they were not ruled by kings" (Wittenberg 2007:98), their "segmentary ... [relatively "democratic"] acephalous society" (Wittenberg 2007:98-99), and the leadership of clan-based "elders" and/or "judges" (Wittenberg 2007:99).

The resistance theology of this sector takes on a distinctive socio-economic shape, however, "within the context of historical struggles and conflicts" (Wittenberg 2007:137); it is a theology of struggle. And the locus of the struggle is the rise of the monarchy. The resistance theology of the am ha'aretz is forged, firstly, in opposition to Egyptian colonial control of the towns of Judea - for though they "shared in the great tradition of the ancient Near East ... they no longer shared the royal-urban imperial values" (Wittenberg 2007:57), and then, secondly, in contestation with the attempts of David and Solomon "to establish an empire according to the Egyptian model" (Wittenberg 2007:57). Wittenberg's analysis is nuanced, and he is careful to point out that, though the am ha'aretz are clearly apprehensive about monarchy, given their memory of the Egyptian model (and their experience of the Canaanite city-states) (Wittenberg 2007:57), they supported David's kingship. Within the "stable world" of an agricultural community, "where wealth came from the land", "everybody had a place, the rich and the poor, even the king, all of whom the am ha'aretz of Judah had come to accept as part of the just order of creation" (Wittenberg 2007:74).

Incrementally, as the monarchic system under David developed ominously oppressive systemic features, so Wittenberg discerns contestation among the am ha'aretz. The stable world, on which so much of the agriculture-based life and wisdom was based, became unstable. As Wittenberg shows, wisdom literature, itself a site of struggle, reflects the emergence of the recognition of a systemic relationship between wealth and poverty. Proverbs 22:2, "The rich and the poor have a common bond, the Lord is the maker of them all" seems to reflect a non-systemic relationship between "the rich" and "the poor" when compared to Proverbs 29:13, "The poor and the oppressor have a common bond, the Lord gives light to the eyes of both". " "The two sayings are almost identical", Wittenberg notes, "but there is a major shift in meaning in the second one - from the neutral 'rich' to the pejorative 'oppressor"" "This shift in emphasis", he continues, "from wealth as a desirable asset and a blessing of God typical of old wisdom, to wealth as a means of oppression, can best be understood ... as a reaction of the old economy to the dynamics of a growing urban-based monetary economy", to the introduction of "Canaanite [city-temple state] business practices, especially interest on loans", systems that "could be seen as being primarily responsible for the exploitation of the rural population" (Wittenberg 2007:75).

With this systemic socio-economic shift, contestation develops within the am ha'aretz, for a certain sector of the am ha'aretz not only benefited from but were coopted by this emerging monarchic city-temple state economic system, and so contributed to the exploitation of "the poorer Judahite fellow citizens who were sinking even deeper into debt and serfdom" (Wittenberg 2007:71). A sector of the am ha'aretz, Wittenberg

9 These are my translations. 
argues, "in the latter part of the monarchy", "became a rich, land-owning class who participated in the oppression of the poorer sections of the people, together with the merchants and other feudatories in the city of Jerusalem" (Wittenberg 2007:71, 133). However, Drawing on the "dangerous insights" (Marcuse 1964) and "dangerous memory" (Metz 1980)) of "their own ancient sacred traditions", especially the Exodus tradition (Wittenberg 2007:14), there remained "a counter-movement" within the am ha'aretz (Wittenberg 2007:71). It is this counter-movement and its resistance theology that is the focus of Wittenberg's scholarship.

For both Mosala and Wittenberg socio-historical method is framed by an eclectic array of liberation theory (West 1991:70-74, 78-79), but with an emphasis on an African Marxist orientated economic analysis. ${ }^{10}$ Their hermeneutic is similar. African liberation theory - specifically and respectively, South African Black Theology and South African Contextual Theology - shapes their interpretive project, including accountability to contemporary poor and marginalised African sectors and responsibility to the sociohistorical realities of similar sectors within the sites of production of biblical texts. Historical-critical methods, and redaction criticism in particular, provide resources for locating a biblical text within its historical period of production. Redaction criticism is key in their analysis (West 2017), for both recognise that the final form of the biblical text is a product of continual ideo-theologically driven reuse (until the canon is closed) (West 2019). What is distinctive about Mosala's and Wittenberg's understanding of redaction criticism is that it is ideo-theological, not simply historical. Sociological theory, and Marxist oriented historical-materialist theory in particular, provide resources for identifying the economic dimensions of the contested site of production that generated a 'text', and for identifying the contending sectoral voices within that text. Marxist oriented notions of 'mode of production', taken up into biblical scholarship by Gottwald and others (West 2020:56), provide them with socio-economic categories for identifying contending and co-opted sectoral voices.

These then are the two ends of an ideological orientation to redactional criticism. At the one end are the voices of the exploited classes; at the other end is the final form of the text. In-between are successive stages of redaction. The purpose of an ideologically determined redaction criticism is precisely to delve for each and every voice, no matter how co-opted and 'redacted'. Identifying poor and marginalised sectoral voices within historical sites of struggle is the focus of Mosala's and Wittenberg's socio-historical work. ${ }^{11}$ They recognise, however, that this oral voice is always 're-presented' by other sectors. For Mosala, the closest we come to this voice is the representation of the prophet; for Wittenberg, it is the representation of the Judahite landowning sector. Both recognise, however, that even this partial representation is itself coopted and represented by the scribal sector, which subsists on and so tends to serve the city-temple state ruling elite sectors, who are responsible for the final redactional compositions and their ideo-

For a detailed analysis of Mosala's use of Marx see: West, "Serving the sighs of the working class in South Africa with Marxist analysis of the Bible as a site of struggle."

11 For an overview of what such a sectoral analysis might look like across 'the Bible', see: Walter Brueggemann, Walter. 1993. Trajectories in Old Testament literature and the sociology of ancient Israel, in Gottwald, Norman K. and Horsley, Richard A. (eds), The Bible and liberation: political and social hermeneutics, Maryknoll, NY: Orbis. 

theologies. ${ }^{12}$

Though a historical orientation is somewhat fashionably unfashionable at this time (Moore and Sherwood 2011), Mosala's and Wittenberg's liberatory project requires the work in order to identify and hear kin voices of struggle within and behind what they understand to be systemically and thoroughly ideo-theologically co-opted biblical texts. Significantly, both Wittenberg and Mosala emphasise the economic dimensions of ancient and contemporary life. That class is constructed and configured racially in South Africa shapes their prioritising in the 1980s of the socio-economic (Terreblanche 2002). Ukpong's "inculturation biblical hermeneutic", though having a broadly 'cultural' orientation, also includes recognition of the "oppressive structures of contemporary economic systems" (Ukpong 1996:208), though his tendency is to foreground emerging globalised economic systems, such as the 'Structural Adjustment Programmes' that have so devastated emerging postcolonial African economies (Ukpong) 1996:207; Ukpong 2002:25-37). In general, African biblical scholarship outside of South Africa has tended to emphasise the religio-cultural aspects of their own African realities, ${ }^{13}$ and where the socio-economic is analysed it tends to be at the 'international' level. Wittenberg and Mosala are more local in their socio-economic analysis, preparing the way, both in terms of contextual emphasis and interpretive method for the work of successive generations of South African biblical scholars. ${ }^{14}$

Like most other African biblical scholars, Mosala's and Wittenberg's project is given its impetus by an already read and regularly used Bible within the South African context of struggle in the 1980s. They take up the hermeneutical tools they do in order to serve poor and marginalised Bible-using communities within contemporary sites of struggle. It is a hermeneutic of reception that gives shape to their methodological choices with respect to a hermeneutic of production.

\section{A hermeneutic of reception}

An African biblical hermeneutics of reception is predicated on two assumptions. The first and most fundamental is the actual presence of the Bible in African contexts among African communities. African biblical scholars recognise the reality across African contexts of an already 'entangled' Bible. I find Achille Mbembe's notion of 'entanglement' useful here. The "time of African existence", argues Achille Mbembe, can be characterised as the "time of entanglement". He goes on to elaborate, arguing that the time of African existence "is neither a linear time nor a simple sequence in which

12 For a fuller analysis see: West, "Serving the sighs of the working class in South Africa with Marxist analysis of the Bible as a site of struggle," 53-56.

13 See also: Dube, Musa W. 2001a. Fifty years of bleeding: a storytelling feminist reading of Mark 5:24-43. in Dube, Musa W. (ed), Other ways of reading: African women and the Bible. Atlanta: Society of Biblical Literature; Dube, Musa W. 2001bDivining Ruth for international relations. in Dube, Musa W. (ed), Other ways of reading: African women and the Bible. Atlanta and Geneva: Society of Biblical Literature and WCC Publications.

14 See for example: Nzimande, Makhosazana K. 2008. Reconfiguring Jezebel: a postcolonial imbokodo reading of the story of Naboth's vineyard (1 Kings 21:1-16). in De Wit, Hans and West, Gerald O. (eds), African and European readers of the Bible in dialogue: in quest of a shared meaning. Leiden: Brill; Mtshiselwa, Ndikho. 2014. A re-reading of 1 Kings 21:1-29 and Jehu's revolution in dialogue with Farisani and Nzimande: negotiating socio-economic redress in South Africa, Old Testament Essays 27(1); Ramantswana, Hulisani .2016. Decolonising biblical hermeneutics in the (South) African context, Acta Theologica Supplement 24, https://doi.org/10.4314/actat.v36i1.11S. 
each moment effaces, annuls, and replaces those that preceded it, to the point where a single age exists within a society. This time is not a series but an interlocking of presents, pasts, and futures, each age bearing, altering, and maintaining the previous ones" (Mbembe 2001:16). In my recent book, The Stolen Bible: From Tool of Imperialism to African Icon", I offer an account of this entanglement (West 2016b). The Bible that comes in European imperial-commercial trading ships in the mid-1600s and which is used to take, among many African things, African cattle, is later, in the 1900s, stolen by African healer-prophet-messiahs, with the clear recognition that those who stole African cattle now have had their own potentially powerful sacred text stolen by those whose cattle were stolen (West 2016b:66-75, 252-60). The Bible that is translated by missionaries who despise African languages and cultures, yet have to turn to those same African languages and cultures in order to translate, is the Bible that Africans pry from missionary control and appropriate for their own purposes precisely because of those languages and the African reader discerned religio-cultural resonances between biblical cultures and their own African cultures (West 2016b:164-231, 32-43). The Bible that is used by Whites to craft the racial-economic system of apartheid is used by Blacks to assert Black dignity and claim political, legal, and economic liberation (West 2016b:36975, 26-28). The Bible that is used by Whites to take Black land is used by Blacks to expropriate land taken by Whites (West 2016b:447-49, 545-61).

The second assumption that undergirds an African reception of the Bible is that the Bible is, in the words of Takatso Mofokeng writing in the 1980s, an "accessible ideological silo or storeroom" of "ideological and spiritual food" for "the Black masses" (Mofokeng 1988:40). While much of African biblical scholarship concurs with the trajectory of early Latin American biblical hermeneutics, in which the Bible is understood to have a liberatory "axis" (West 1983:26-28), the trajectory of South African biblical scholarship I am engaging here rejects the notion that the problem is with the misinterpretation of an inherently liberatory Bible. Mofokeng is clear in his rejection of this argument. "The most commonly held approach", Mofokeng argues, "has been to accuse oppressor preachers of misusing the Bible for their oppressive purposes and objectives. This misuse is based, it is argued, on misinterpretations of biblical texts to support or promote oppressive intentions" (Mofokeng 1988:37). However, he continues, "It is clear that this critique is based on the assumption that the Bible is essentially a book of liberation. This assumption is held in spite of the obvious presence in the Bible of texts, stories, and books which can only serve an oppressive cause" (Mofokeng 1988:37). "We contend", he counters, "that there are stories and texts which are basically oppressive and [their] interpretation (not misinterpretation) only serves the cause of oppression. On the contrary [,] it is (in fact) their interpretation and use for liberation that would constitute misinterpretation and misuse" (Mofokeng 1988:37).

Formally-trained black biblical scholars and theologians are part of the problem, argues Mofokeng, for they "have been brought into the ideological universe of the dominant and oppressive Christian world and accepted it" (Mofokeng 1988:37), and so attempt to "save" or "co-opt" inherently oppressive biblical texts (Mofokeng 1988:38). Such attempts to use "oppressive texts for the oppressed only serve the interests of the oppressors who desire to have the oppressed under the same cultural, spiritual and ideological (sic) as themselves because they are in control of it" (Mofokeng 1988:38). Mofokeng calls on "formally-trained" black biblical scholars and theologians to align 
Towards inclusive and collaborative African biblical hermeneutics of reception and production 11 themselves with the "hermeneutical approach of lay Christians" (Mofokeng 1988:38), in which these "untrained black hermeneutists" bring their social context "into a dynamic and fruitful interaction with the Bible", so that "[t]he progressive elements of the black life experience, history and culture interact with the progressive life experience, histories and cultures of some biblical communities" (Mofokeng 1988:39, 41).Black biblical scholars and theologians "who are organically connected to the above Christian hermeneutical communities but who also stand with both feet in the liberation struggle do not frown", insists Mofokeng, "on this hermeneutical approach of lay Christians. On the contrary they lift the above hermeneutical exercise to a higher formal level" (Mofokeng 1988:41), joining with the Black masses "to assert their claim on the Bible as a weapon of ideological and spiritual struggle for liberation". "As they assert this claim", Mofokeng continues, "a new kind of struggle ensues, namely, the struggle for the Bible or, to be more precise, the struggle for control of the Bible" (Mofokeng 1988:39). Profoundly, Mofokeng understands how a hermeneutic of reception requires a hermeneutic of production.

Mofokeng does not develop how he understands the task of 'lifting' lay hermeneutical practice "to a higher level", but as we have seen, his comrade and dialogue partner, Mosala, does. Mosala takes up the hermeneutical task where Mofokeng leaves off, using Marxist theory and method to construct a historical-materialist biblical hermeneutics of liberation (West 2020). What Mofokeng is clear about, however, is that the "analytical tools" forged by Black Theology in collaboration with the masses of lay Black Christians must serve what Marx referred to as "the sigh of the oppressed" (Marx 2010:175) and what Mofokeng refers to below as the "story of pain, fears, and hopes" of "the downtrodden of this world":

Using these analytical tools as members of a silenced, marginalized and sometimes ignored race, they discover the silenced, ignored and marginalized people in the Bible and develop an affinity with them. They also discover the text behind the text of the Bible - a text that has been silenced but one that speaks through this silence about the struggles of the silenced and marginalized people of the Bible. As members of a people whose story of pain, fears and hopes has been suppressed, they are enabled, by their physical and psychological scars, together with the analytical tools they have chosen, to discover the suppressed and forgotten stories of the weak and the poor of the Bible. These seem, according to them, to be the stories wherein God is identifying with the forgotten and the weak and is actively retrieving them from the margins of the social world. It is through these stories that God, the creator of humans, is manifested as the God of the oppressed and accepted as such. This creator God acts incarnately in Jesus to end the rampant enmity in creation and restore real humanity to people. Only the reading of these stories of the downtrodden God among the downtrodden of this world strengthens the tormented faith of the oppressed of our time, as well as enhancing the quality of their commitment to the physical struggle for liberation. This discovery constitutes the liberation of the Bible from the clutches of the dominant in the Christian fold who impose the stories that justify their victories onto the oppressed (Mofokeng 1988:41; see also West 2020).

Mofokeng invokes a theological trajectory given its shape by "silenced" voices and texts, 
recognising together with Wittenberg (and to some extent Mosala) that a remnant resisting presence is recoverable. What all three of these South African liberation hermeneutics scholars recognise is the required presence of 'lay' (Mofokeng) or 'commoner' (Mosala) or 'poor and oppressed' (Wittenberg) Bible-using 'readers' (Wittenberg 1993:5). Reflecting back on this period and its contribution to African biblical scholarship, Ukpong too recognises the inclusion within African biblical scholarship of "ordinary African readers (that is, non-biblical scholars) as important partners” (Ukpong 2000a:23).

\section{Inclusive reception and collaborative production hermeneutics}

How each of these African scholars goes about actually working with African ordinary users of the Bible is different. Mosala laments the lack of methodological capacity among African commoner Christians (Mosala 1996:57), but does not put forward or implement a clear procedure for working hermeneutically with this sector. Ukpong shares similar concerns about popular West African ways of reading the Bible, seeing them as a "serious challenge" (Ukpong 2000b:593), and gives glimpses of how an overt use of inculturation method at work on Matthew 20:1-16, a parable about day-labourers in first-century Palestine, interacts with "the situation of day labourers in Southern Nigeria" when the method is used among them and with them (Ukpong 2001:196). Though Ukpong is not clear and precise about his inclusive reception and collaborative production interpretive processes, he acknowledges that he is following the kinds of interpretive processes forged by Wittenberg and the Institute for the Study of the Bible (ISB). Wittenberg's work is overt about method, but his emphasis is on the potential resistance theology resources that the method recovers from the final form of the biblical text. In this regard, Wittenberg and Ukpong are very similar. Where Wittenberg is distinctive is, first, in offering popular forms of his biblical studies method (Wittenberg 1993), and, second, in his recognition that inclusive and collaborative hermeneutical work requires an organised and institutionalised site in which socially engaged biblical scholars and ordinary readers of the Bible collaborate (ISB 2000:14-16). Mofokeng, as a theologian, offers a theological trajectory constructed from across biblical texts, centred on Christology (Mofokeng 1983), of "the downtrodden God among the downtrodden of this world". While Wittenberg reconstructs a resistance theology trajectory of "an Old Testament theology" (Wittenberg 1993: xii), Mofokeng does something similar with the New Testament (Mofokeng 1987).

My own work since the late 1980s follows in these footsteps, but diverges in terms of method. Briefly, ${ }^{15}$ while I acknowledged the significant contribution of the sociohistorical methods advocated by Wittenberg, Mosala, and Ukpong, I also recognised that an inclusive reception and collaborative production hermeneutic could not begin with the socio-historical. Socio-historical method excludes what I came to call 'ordinary readers'. So within the Institute for the Study of the Bible (which then became the Institute for the Study of the Bible \& Worker Ministry Project, which then became the Ujamaa Centre) I began to experiment over the next thirty years with how we might use literary-narrative method to include ordinary readers in discerning contending voices within (and then behind) the biblical text.

15 For the longer version see West, Biblical hermeneutics of liberation. 
My early work grappled with the arguments put forward by Norman Gottwald, Itumeleng Mosala, and Elisabeth Schüssler Fiorenza about why socio-historical method ought to be privileged in liberation hermeneutics and why literary-narrative method risked sustaining forms of "neo-orthodox theology" in which the Bible was understood as offering a singular authoritative voice (Fiorenza 1983:135-54), rather than the reality of contending voices. My argument then (West 1991:146-54), and now (West 2019), is that literary-narrative method offers an egalitarian entry point for an inclusive and collaborative hermeneutic, working from Mosala's "glimpses" within the text of contending voices to a more in-depth analysis of the socio-historical sites of production that generated this contestation and co-optation.

Gottwald's, Mosala's, and Schüssler Fiorenza's (as well as Wittenberg's and Draper's $)^{16}$ concerns are understandable, given the rudimentary nature of literarynarrative method within biblical scholarship in the late 1970s and early 1980s. But literary-narrative tools have come a long way since. Mosala is justifiably worried by interpretations that follow the ideo-theological grain of what is a co-opted text (Mosala 1989a:123-53, 73-89), what the literary biblical scholar Denis Olson refers to as the "constructive literary approaches" characteristic of the 1970s and 1980s, in which "scholars often assumed a basic unity, structure, and coherence in the text" (Olson 2010:16). However, continues Olson, with the recognition of the presence of real readers and their role "in constructing meaning from texts", "literary scholars began to question the new critic's assumption about the stability of literary texts with a unified meaning. They also resisted structuralism's assumption of a set of universal binary oppositions that transcend cultural and social location" (Olson 2010:19). Alongside this readercentred generated recognition, text-centred approaches themselves became more focussed "'in' the details of the text itself", recognising both the text's "internal complexity" and the text's "gaps and omissions" (Olson 2010:19). The grain of the text was destabilised from without by the reader and from within by the text's own detail and (post-structural) gaps, each of which are ideologically determined (in both senses of the English word). Such "deconstructive literary approaches" (Olson 2010:19) are better equipped to do the work Mosala envisages at the textual level, and lend themselves to inclusive and collaborative work. Using deconstructive literary-narrative method, inclusive and collaborative interpretive work is able to detect more detailed "glimpses" of the struggles that produced the text, in the text.

Two examples from the 'Contextual Bible Study' (CBS) work of the Ujamaa Centre reflect how we move from literary-narrative to socio-historical contestation. Our work on 2 Samuel 13:1-22, the story of the rape of Tamar, separates this text from the patriarchal and monarchical narrative that has co-opted it. Our claim is not that 2 Samuel 13:1-22 is devoid of redactional co-optation; our claim is more modest, using literarynarrative analysis to facilitate inclusive and collaborative recognition of internal textual gendered contestation and the option to go behind the text to the kinds of socio-historical gendered contestation taking place in the ancient world. ${ }^{17} \mathrm{~A}$ second example is even

16 See for example: Draper, Jonathan A. 1995. Wandering radicalism or purposeful activity? Jesus and the sending of messengers in Mark 6:6-56, Neotestamentica 29.

17 See for example: Gerald O. West, "Deploying the literary detail of a biblical text (2 Samuel 13:1-22) in search of redemptive masculinities," in Interested readers: essays on the Hebrew Bible in honour of David J.A. Clines, ed. James K. Aitken, Jeremy M.S. Clines, and Christl M. Maier (Atlanta: Society of Biblical 
more explicit about the move from literary-narrative method to socio-historical method. Working together with my colleague Sithembiso Zwane on the same parable as Ukpong (Matthew 20:1-16), we have offered local community projects we work with two 'texts' to interpret, with half the group interpreting Matthew's religiously oriented redaction of the parable and other the half a partially recovered pre-redaction economically oriented 'source' parable. ${ }^{18}$ Here too we begin with a literary-narrative inclusive and collaborative interpretation, through which ordinary readers recognise internal economic contestation, and then move overtly to the socio-historical sectoral economic contestation within the text's site of production in first- century Palestine (West and Zwane 2013).

The Ujamaa Centre has become increasingly overt about the kind of Bible we work with. The values or orientations that shape our work are the following: Community, Criticality, Collaboration, Change, Context, and Contestation (West 2015). The last has been added relatively recently, in response to a growing recognition that we should be more overt about the reality of a Bible that is a site of struggle and contestation, both in terms of its sites of production and its sites of reception.

\section{Conclusion}

South African Africa-oriented biblical scholarship in the 1980s emphasised the importance of the recognition, both in the academy and in local communities of ordinary users of the Bible, that the Bible is itself, intrinsically and inherently, a site of struggle. Scholars like Gunther Wittenberg and Itumeleng Mosala advocated socio-historical analysis of a text's site of production and the socio-economic forces at work within this site. This article has argued that this is a distinctive contribution of South African Africaoriented biblical scholarship to African biblical scholarship. Though other African biblical scholars, like Justin Ukpong, would take up aspects of this work, the pioneers of a biblical hermeneutics of production were South Africans.

Though the emphasis of these African biblical scholars was on a hermeneutics of production, like almost all other African scholars, they embraced a biblical hermeneutics of reception, with African contexts as the subject of interpretation. Each of these biblical scholars offered African communities of reception both their interpretive method and the theological outcomes of their method. Wittenberg emphasised the forms of resistance theology that socio-historical method offered to contemporary sites of resistance. Mosala's emphasis was almost entirely on method, so much so that one could argue that for Mosala method is theology.

Each of these South African biblical scholars recognised a role for ordinary African users of the Bible in the interpretive process. Mosala invokes their presence and their potential for guiding the socially engaged biblical scholar in the search for resonances between contemporary and ancient kin struggles. Wittenberg not only acknowledges their collaborative interpretive potential, but establishes a site, which is now the Ujamaa Centre, within which such collaboration can be nurtured. It is from this inclusive and collaborative site that 'Contextual Bible Study' has emerged as both a hermeneutic of inclusive reception and a hermeneutic of collaborative exploration of the Bible's contested sites of production. 


\section{BIBLIOGRAPHY}

Brueggemann, Walter. 1993. Trajectories in Old Testament literature and the sociology of ancient Israel. In Gottwald, Norman K. and Horsley, Richard A. (eds), The Bible and liberation: Political and social hermeneutics. Maryknoll, NY: Orbis, 201-26.

Chaney, Marvin L. 2006. Micah - Models Matter: Political Economy and Micah 6:9-

15. In Esler, Philip F. Ancient Israel: The Old Testament in its social context. Minneapolis: Fortress Press, 145-60.

Croatto, J. Severino. 1983. Biblical hermeneutics in theologies of liberation. In Fabella, Virgina and Torres, Sergio (eds), Irruption of the Third World: Challenge to theology. Maryknoll: Orbis, 140-41.

Deist, Ferdinand. 1982."Idealistic theologiegeschichte, ideology critique and the dating of oracles of salvation." Paper presented at the SA Society for the Study of the Old Testament Congress (22nd \& 23rd), Pretoria (1979) and Johannesburg (1980), 1982.

Dijkhuizen, Petra. 2013. The State of Our Discipline, Neotestamentica 47(2) 247-62.

Draper, Jonathan A. 1991. "For the Kingdom is inside of you and it is outside of you": Contextual exegesis in South Africa (Lk. 13:6-9)." In Hartin, Patrick J. and Petzer, Jacobus H. (eds.), Text and interpretation: New approaches in the criticism of the New Testament. Leiden: E.J. Brill235-57.

. 1995. Wandering redicalism or purposeful activity? Jesus and the sending of messengers in Mark 6:6-56, Neotestamentica 29: 187-207.

Dube, Musa W. 2001 a. Divining Ruth for international relations. In Dube, Musa W. (ed.), Other ways of reading: African women and the Bible, e. Atlanta and Geneva: Society of Biblical Literature and WCC Publications, 179-95.

. 2001b. Fifty years of bleeding: A storytelling feminist reading of Mark 5:2443. In Dube, Musa W. (ed), Other ways of reading: African women and the Bible. Atlanta: Society of Biblical Literature50-60.

Fiorenza, Elisabeth Schüssler. 1983. In memory of her: A feminist theological reconstruction of Christian origins. London: SCM.

Fowl, Stephen. 1995. Texts don't have ideologies. Biblical Interpretation 3: 15-34.

Frostin, Per. 1988. Liberation theology in Tanzania and South Africa: A First World interpretation. Lund: Lund University Press.

Gottwald, Norman K. 1979. The tribes of Yahweh: A sociology of the religion of liberated Israel, 1250-1050 B.C. Maryknoll, New York: Orbis. . 1999. The tribes of Yahweh: A sociology of the religion of liberated Israel, 1250-1050 Bce. Sheffield: Sheffield Academic Press; Maryknoll: Orbis.

Herzog, William R. 1994. Parables as subversive speech: Jesus as pedagogue of the oppressed. Louisville: Westminster John Knox.

Holter, Knut. 2002. Old Testament research for Africa: A critical analysis and annotated bibliography of African Old Testament dissertations, 1967-2000. New York: Peter Lang.

ISB. 2000. The tenth anniversary celebration and evaluation. Institute for the Study of the Bible and The House of Studies for Worker Ministry. The Worker Ministry Project. Pietermaritzburg.

Lategan, Bernard C. 1984. Current issues in the hermeneutical debate, Neotestamentica 
18: $1-17$.

LeMarquand, Grant. 2000. A bibliography of the Bible in Africa. In West, Gerald O. and Dube, Musa W. (eds), The Bible in Africa: Transactions, trajectories, and trends. Leiden: E.J. Brill,633-800.

Marcuse, Herbert. 1964. One-dimensional man: Studies in the ideology of advanced industrial society. Boston: Beacon Press.

Marx, Karl. 2010. Contribution to the critique of Hegel's Philosophy of Law (1843-44). In Marx, Karl and Engels, Friedrich (eds.), Collected Works: Volume 3, Karl Marx March 1843-August 1844. London: Lawrence \& Wishart, 175-87.

Masenya, Madipoane, and Hulisani Ramantswana. 2012. Anything new under the sun of South African Old Testament scholarship? African Qoheleths' review of Ote 1994-2010, Old Testament Essays 25: 598-637.

Mbembe, Achille. 2001. On the Postcolony. Berkeley: University of California Press.

Metz, Johann Baptist. 1980. Faith in history and society: Toward a practical fundamental theology. New York: Seabury Press.

Mofokeng, Takatso. 1988. Black Christians, the Bible and liberation. Journal of Black Theology 2: 34-42.

Mofokeng, Takatso A. 1983a. A Black Christology: A new beginning. Journal of Black Theology in South Africa 1(1): 1-17. .1983b. The crucified among the cross-bearers: Towards a Black Christology. Kampen: H. Kok.

Moore, Stephen D., and Sherwood, Yvonne. 2011. The Invention of the Biblical Scholar: A Critical Manifesto. Minneapolis: Fortress Press.

Mosala, Itumeleng J. 1989a. Biblical and black theology in South Africa. Grand Rapids: Eerdmans.

. 1989b. Race, class, and gender as hermeneutical factors in the African Independent Churches. Pretoria: Unpublished report to the HSRC.

-1996. Race, class, and gender as hermeneutical factors in the African Independent Churches' appropriation of the Bible, Semeia 73: 43-57. .1986. The use of the Bible in black theology. In Mosala, Itumeleng J. and Tlhagale, Buti (eds.), The unquestionable right to Be free: Essays in black theology. Johannesburg: Skotaville, 175-99.

Mtshiselwa, Ndikho. 2014. A re-reading of 1 Kings 21:1-29 and Jehu's revolution in dialogue with Farisani and Nzimande: Negotiating socio-economic redress in South Africa, Old Testament Essays 27(1): 205-30.

Nzimande, Makhosazana K. 2008. Reconfiguring Jezebel: A postcolonial Imbokodo reading of the story of Naboth's Vineyard (1 Kings 21:1-16). In de Wit, Hans and West, Gerald O. (eds.), African and European readers of the Bible in dialogue: In quest of a shared meaning. Leiden: Brill, 223-58.

Olson, Dennis T. 2010. Literary and rhetorical criticism. In Dozeman, Thomas B. (ed.), Methods for Exodus. Cambridge: Cambridge University Press, 13-54.

Ramantswana, Hulisani. 2016. Decolonising Biblical hermeneutics in the (South) African context, Acta Theologica Supplement 24: 178-203. https://doi.org/10.4314/actat.v36i1.11S.

Scott, James C. 1990. Domination and the arts of resistance: Hidden transcripts. New Haven and London: Yale University Press. 
Smit, Dirk J. 1990. The ethics of interpretation: And South Africa., Scriptura 33: 2943.

Terreblanche, Sampie. 2002. A history of inequality in South Africa, 1652-2002. Pietermaritzburg: University of Natal Press.

Tshehla, Maarman S. 2014. Africa, where art thou? Pondering post-Apartheid South African New Testament scholarship. [In English], Neotestamentica 48(2): 259-81.

Ukpong, Justin S. 2001. Bible reading with a community of ordinary readers. In Getui, Mary, Maluleke, Tinyiko S., and Ukpong, Justin S. Interpreting the New Testament in Africa. Nairobi: Acton, 188-212.

.2000a. Developments in Biblical interpretation in Africa: Historical and hermeneutical directions, Journal of Theology for Southern Africa 108: 3-18. - 2000b. Developments in Biblical interpretation in Africa: Historical and hermeneutical directions." In West, Gerald O. and Dube, Musa W. (eds.), The Bible in Africa: Transactions, trajectories and trends. Leiden: E.J. Brill, 11-28. - 1996. The parable of the shrewd manager (Lk 16:1-13): An essay in the inculturation of Biblical hermeneutics, Semeia 73: 189-210.

. 2000c. Popular readings of the Bible in Africa and implications for academic readings: Report on the field research carried out on oral interpretations of the Bible in Port Harcourt Metropolis, Nigeria under the auspices of the Bible in Africa Project, 1991-94. In West, Gerald O. and Dube, Musa W. (eds.), The Bible in Africa: Transactions, trajectories, and trends. Leiden: E.J. Brill, 582-94. . 2002. Reading the Bible in the global village: Issues and challenges from African readings. In Ukpong, Justin S. (ed.), Reading the Bible in the global village: Cape Town. Atlanta: Society of Biblical Literature, 9-39.

- 1995. Rereading the Bible with African eyes, Journal of Theology for Southern Africa 9: 3-14.

Von Rad, Gerhard. 1975. Old Testament theology: The theology of Israel's historical traditions. Vol. 2. London: SCM Press.

West, Gerald O. 2019. Scripture as a site of struggle: Literary and socio-historical resources for prophetic theology in post-colonial, post-Apartheid (neo-colonial?) South Africa. In Havea. Jione (ed.), Scripture and resistance. New York and London: Lexington/Fortress Academic149-63.

West, Gerald O. 2016a. Accountable African Biblical scholarship: Post-colonial and tri-polar. Canon\& Culture 20: 35-67.

2019. The Bible and/as the lynching tree: A South African tribute to James $\mathrm{H}$. Cone, Missionalia 46(2): 236-54. http://missionalia.journals.ac.za/pub/article/view/312.

. 1995. Biblical hermeneutics of liberation: Modes of reading the Bible in the South African context. Second Revised ed. Maryknoll and Pietermaritzburg: Orbis Books and Cluster Publications, 1995. Cluster Publications 1991. . 2013. Deploying the literary detail of a Biblical text (2 Samuel 13:1-22) in search of redemptive masculinities. In Aitken, James A., Clines, Jeremy M.S. and Maier, Christl M. (eds.), Interested readers: Essays on the Hebrew Bible in honor of David J.A. Clines. Atlanta: Society of Biblical Literature, 297-312.

. 2009. Interpreting 'the Exile' in African Biblical scholarship: An ideotheological dilemma in postcolonial South Africa. In Becking, Bob and Human, 
Dirk (eds.), Exile and suffering: A selection of papers read at the 50th

Anniversary Meeting of the Old Testament Society of South Africa Otwsa/Otssa, Pretoria August 2007. Leiden: Brill, 247-67.

2017. Redaction criticism as a resource for the Bible as 'a site of struggle', Old Testament Essays 30(2): 525-45. 2020. Serving the sighs of the working class in South Africa with Marxist analysis of the Bible as a site of struggle, Rethinking Marxism 32(1): 41-65. https://doi.org/10.1080/08935696.2019.1694287.

- 2016b. The stolen Bible: From tool of imperialism to African icon. Leiden and Pietermaritzburg: Brill and Cluster Publications.

.2004. Taming texts of terror: Reading (against) the gender grain of 1 Timothy, Scriptura 86: 160-73.

_ 2015. "Reading the Bible with the marginalised: the value/s of contextual Bible reading." Stellenbosch Theological Journal 1 (2): 235-261.

West, Gerald O., and Zwane, Sithembiso. "Why are you sitting there?" Reading Matthew 20:1-16 in the context of casual workers in Pietermaritzburg, South Africa. In Wilkinson, Nicole Duran and Grimshaw, James (eds.), Matthew: Texts@Contexts. Minneapolis: Fortress Press, 175-88.

White, Hayden. 1978. The tropics of discourse: Essays in cultural criticism. Baltimore: Johns Hopkins University Press.

Wittenberg, Gunther H. 1993. Prophecy and protest: A contextual introduction to Israelite prophecy. Pietermaritzburg: Cluster Publications. - 2007. Resistance theology in the Old Testament: Collected essays. Pietermaritzburg: Cluster Publications. 